\title{
Kis- és középvárosok szerepe a területi fejlődésben - Beszámoló a Magyar Regionális Tudományi Társaság XIV. vándorgyüléséről
}

\author{
The role of small and medium sized cities in regional \\ development - Report on the 14th Annual Meeting of \\ Hungarian Regional Science Association
}

KOVÁCS SÁNDOR ZSOLT, RÁCZ SZILÁRD

\begin{abstract}
KOVÁCS Sándor Zsolt: tudományos segédmunkatárs, MTA Közgazdaság- és Regionális Tudományi Kutatóközpont, Regionális Kutatások Intézete; 7621 Pécs, Papnövelde u. 22.; skovacs@rkk.hu

RÁCZ Szilárd: tudományos titkár, MTA Közgazdaság- és Regionális Tudományi Kutatóközpont, Regionális Kutatások Intézete; 7621 Pécs, Papnövelde u. 22.; szracz@rkk.hu
\end{abstract}

\begin{abstract}
Sándor Zsolt KOVÁCS: junior research fellow, Institute for Regional Studies, Centre for Economic and Regional Studies, Hungarian Academy of Sciences; Papnövelde u. 22., H-7621 Pécs, Hungary; skovacs@rkk.hu

Szilárd RÁCZ: scientific secretary, Institute for Regional Studies, Centre for Economic and Regional Studies, Hungarian Academy of Sciences; Papnövelde u. 22., H-7621 Pécs, Hungary; szracz@rkk.hu
\end{abstract}

A Magyar Regionális Tudományi Társaság vándorgyủlése 2016-ban immár harmadik alkalommal került megrendezésre a határon túl. A XIV. vándorgyűlés helyszíne és időpontja a nagyváradi Partiumi Keresztény Egyetem (PKE) volt szeptember 15-én és 16-án, tematikáját pedig a kis- és középvárosok területi fejlődésben játszott szerepe adta. Az elhangzott mintegy száz előadás a városi fejlődés és fejlesztés különböző aspektusait, kapcsolódó területeit mutatta be. A hagyományokat megőrizve az első nap délelőttjén a társaság közgyủlése zajlott. Az elnöki beszámolóból a tagság megismerhette az MRTT előző évi tevékenységét és 2017-re szóló terveit, míg a Számvizsgáló Bizottság jelentése az MRTT stabil pénzügyi helyzetét mutatta be. Ezt követően a jelen lévő tagság a Regionális Tudományért Díj odaítéléséről szavazott. A rendezvény társszervezője a Partiumi Területi Kutatások Intézete (PTKI) volt, amely a PKE keretein belül önálló kutatási egységként működik 2015 óta, létrehozásának célja a Partium területét érintő regionális kutatások tudatos felvállalása, szervezése, és a meglévő interdiszciplináris kutatási kapacitás összefogása. A PTKI 2016. április 28-án

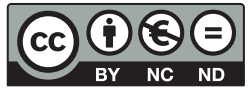


együttműködési megállapodást kötött az MRTT-vel, és ezzel a társaság 14., partiumi tagozatává vált.

2016-ban új elemmel bővült a rendezvény programja, nevezetesen az adott évben a tudományterületünkön megjelent könyvek - jelen esetben négy publikáció - közreadásával: az Akadémiai Kiadó Modern Regionális Tudomány sorozatában megjelent, Dusek Tamás és Kotosz Balázs által jegyzett Területi statisztika, a Fábián Attila és Pogátsa Zoltán által szerkesztett Az európai kohéziós politika gazdaságtana címü kötetek, valamint a Dialóg Campus Kiadó Studia Regionum sorozatában kiadott, Nárai Márta és Reisinger Adrienn által írt Társadalmi felelősségvállalás és részvétel - a lokális és területi közösségi folyamatokban címü kötet és Rechnitzer János, az MRTT elnöke A területi töke a városfejlődésben - A Györ-kód címmel megjelent monográfiájának bemutatására került sor.

A 130 fős hallgatóságot Tolnay István, a Partiumi Keresztény Egyetem igazgatótanácsi elnöke köszöntötte, majd Varga Attila, a PTE Közgazdaságtudományi Kar professzorának elnökletével megkezdődött az angol nyelvű plenáris ülés.

A nyitó előadást Manfred Kühn (Leibniz-Institut für Raumbezogene Sozialforschung, Erkner) tudományos főmunkatárs tartotta a kis- és középvárosok perifériára szorulásának hajtóerőiről. Az előadás kiindulópontja a városi feladatmegosztás változása volt, melynek tulajdoníthatóan a nagyvárosi centrumok növekedése a kis- és közepes városok rovására történt. Az utóbbiak esetében három tényező erősíti a periferizációt: a metropolisztérségektől való függés; az innovációs, közlekedési és társadalmi infrastruktúrákhoz, hálózatokhoz való kapcsolódás lehetőségének hiánya; valamint a fiatal, magasan kvalifikált munkaerő elvándorlása. A periferizáció - ebben a megközelítésben - a társadalmi-gazdasági, demográfiai és politikai folyamatok eredményeképpen magyarázza az érintett városok, régiók lemaradását, a területi különbségek növekedését. E folyamatok megállításának lehetősége az erős helyi kormányzatban és döntéshozatalban, a helyben meglevő vállalkozások üzletpolitikájában gyökerezhet.

Natasa Pichler-Milanović, a Ljubljanai Egyetem tudományos fömunkatársa a közép-európai kis- és középvárosok fejlődése előtt álló lehetőségeket mutatta be. Az Európai Unió lakosságának 20\%-a hetven - 500 ezer fönél népesebb - nagyvárosban él, további 40\%-a pedig 100-500 ezer lakosú mintegy 600 városban, ami előrevetíti a kis- (és közepes) méretű városok leértékelődését az országok városhálózataiban. Több nagy nemzetközi kutatás (ESPON, INTERREG stb.) alapján látható, hogy a központi szereppel nem rendelkező városoknak egyik kitörési pontja a kooperáció, azon belül is az uniós szinten preferált nemzetközi, határon átnyúló együttműködés. Meg kell jegyezni, hogy ebben az esetben többszintű (uniós, nemzeti, helyi) megközelítések, szabályozási kérdések merülnek fel, amelyeket meg kell oldani. Az előadó külön felhívta a figyelmet a szakterületen müködő civil szerveződések, tudományos társaságok fontosságára ezekben a folyamatokban.

Pogátsa Zoltán, a Nyugat-magyarországi Egyetem docensének előadása az Európai Unió kohéziós politikai paradigmaváltásának és reformjának alapjául 
szolgáló Barca-jelentést értékelte. Kritikája a politikai anomáliákat és a társadalmi kohézió hiányosságait emelte ki a jelentés kapcsán. Hangsúlyozta, hogy ezek az anomáliák nagymértékben hozzájárultak ahhoz, hogy a források konvergenciahatása elmaradt a várakozásoktól. Mindezen kritikai megjegyzések ellenére is - véleménye szerint - a Barca-jelentés hozzájárult ahhoz, hogy napjainkra jelentősen átalakuljon a kohéziós és strukturális politika. A fejlesztési források transzfere ma már az Európai Bizottság és a tagországok között létrejött partnerségi szerződéseken keresztül valósul meg. A 2014 és 2020 közötti programozási időszakban, a korábbitól eltérően, már a több alapból (multifund) történő finanszírozás és a forráskoncentráció jellemző. A helyi alapú (placebased) fejlesztés új eszközökkel (CLLD, ITI, SUD) gazdagodott, s továbbra is jelentős források állnak rendelkezésre a transznacionális, határ menti nemzetközi együttműködésekre.

Lados Mihály, az MTA KRTK Regionális Kutatások Intézetének tudományos főmunkatársa a smart city modellekről, azok gyökereiről és megvalósulási lehetőségeiről számolt be, utalva a kis- és középvárosok adaptációs lehetőségeire, gyakorlatára. Az okos városok koncepciója a városi szén-dioxid-kibocsátás növekedésének, a klímaváltozásnak és a migrációs hullámoknak a globális problémájára kíván válaszokat adni. Az előadó bemutatta a koncepció alapján készült korábbi nemzetközi modelleket, az Európai Unió által is finanszírozott kutatásokat (pl. Smarter Planet, Real Corp stb.). Ezt követően néhány európai és magyar példát ismerhetett meg a hallgatóság, olyan települési esettanulmányokat, ahol kisebb (Szolnok) vagy nagyobb mértékben (Győr, Veszprém) alkalmaztak okos technológiákat.

A magyar nyelvű plenáris ülésen Rechnitzer János, a Széchenyi István Egyetem professzora az átalakuló magyar városhálózatról és abban a kis- és középvárosok szerepéről szóló előadásban vette sorra a hazai tudományos közösség által folytatott városkutatások fóbb szakaszait - a nagyvárosvizsgálatokat, a városhálózatok és funkciók elemzését, a városrendszer, a várostér és a városi társadalom kutatását. Az egyes szakaszoknál az MRTT elnöke külön kitért a tudományos eredményekre és azok területi politikai jelentőségére, megvalósítására. Zárásként a magyar városhálózat kelet-közép-európai térben játszott szerepével, lehetőségeivel foglalkozott, kiemelve az iparági körzetek, a funkcionális várostérségek jelentőségét. Megjegyezte, hogy a város korántsem „túlkutatott" tudományos téma, a tudományos kutatásnak nagyobb figyelmet kell fordítania a város és várostérség kormányzására, a smart city koncepciók, a városhasználat kidolgozására, emellett vizsgálandó kérdések lehetnek a humán tőke, a kultúra, a felsőoktatás, a kreatív tényezők, az új gazdasági szereplők, a térkapcsolatok hatásai a városfejlődésre.

Illés Sándornak, az Aktív Társadalom Alapítvány elnökének, és Kincses Áronnak, a Központi Statisztikai Hivatal főosztályvezető-helyettesének előadása Migráció, települési hálózatok a Kárpát-medencében címmel hangzott el, alapját a 2001. és 2011. évi népszámlálási adatbázisok adták, amelyekből Kincses 
Áron migrációs trendeket és települési hálózatokat rajzolt fel. Megállapításaik a következők: Magyarország migrációs bevándorlási tere folyamatosan bővül, a szomszédos országok súlya meghatározó maradt, de folyamatosan csökkenni fog. A két népszámlálás közötti adatok alátámasztják Magyarországon a lokális migrációs szereptől a globális felé történt elmozdulást. A külföldi állampolgárok területi eloszlása különbözik a magyar népességétől, az országos hatásokat jelentősen felülmúlják az általuk preferált térségekben (Közép-Magyarország, határ menti járások és a Balaton régió) érezhető befolyásuk.

Somlyódyné Pfeil Edit, a Széchenyi István Egyetem docense a hatékony városigazgatás lehetőségeit foglalta össze az uniós elvárások és a közigazgatásfejlesztés új stratégiai irányainak metszetében. Az uniós elvárásoknak való megfelelés, a területi kohézióra való törekvés a metropolisztérségek mellett felértékelhetné a kis- és középvárosok szerepét. Erre azonban csak akkor van esély, ha kooperáció segítségével a városok kölcsönhatásán alapuló policentrikus struktúrába szerveződnének, vagy ha önigazgatáson alapuló funkcionális várostérséget alkotnának - a kritikus tömeg és így a metropoliszok versenytársaiként való megjelenés érdekében. Ehhez többszintű kormányzásra, place-based szemléletre és az egymással kooperáló ágazati és területi szintű szakpolitikák fejlett rendszerére lenne szükség. A mai magyar viszonyokat áttekintve azonban az előadó negatív képet tárt a hallgatóság elé: a részvételi demokrácia szintje aggályos, a mezopolitikák nem működnek, az ágazatok közötti együttműködések és a területi szakpolitikák hiányoznak, de ami a legfontosabb kritikai észrevétel volt, hogy a centralizált államnak a többszintű kormányzásra nincs igénye. A hálózati kormányzás egyetlen értékelhető elemeként a vidékfejlesztési gyakorlat említhető meg.

A plenáris ülés zárásaként Szilágyi Ferenc, a PKE docense, a PTKI igazgatója a Partium városhálózatáról, határon átnyúló városi kapcsolatairól értekezett. Az előadás első felében a térség lehatárolásának történelmi változásait mutatta be, olyan fordulópontokhoz kötve a határváltozásokat, mint a Habsburg, illetve a török fennhatóság, a trianoni események, a második bécsi döntés vagy a román közigazgatási reformok. Ezt követően a városokban 1910 óta lezajlott demográfiai változásokról, az etnikai átrendeződésről kaptak képet a konferencia résztvevői, majd a partiumi városok határon átnyúló kapcsolatainak értékelése következett. A határhoz közeli nagyvárosi erőterek vizsgálata alapján kimutatható, hogy a közös határszakasz nagyobb részén $(194 \mathrm{~km})$ a román nagyvárosok (Arad, Nagyvárad, Szatmárnémeti) dominanciája jellemző az együttműködésekben, 141 km hosszan a magyar városok (Békéscsaba, Debrecen, Szeged), míg $88 \mathrm{~km}$ esetében egyik városcsoport hatása sem kiemelkedő.

A plenáris ülést követően került sor az MRTT által alapított díjak ünnepélyes átadására. A Regionális Tudományért Díjat a társaság közgyủlésének egyhangú határozatával Nemes Nagy Józsefnek, az Eötvös Loránd Tudományegyetem Természettudományi Kar egyetemi tanárának, a Magyar Regionális Tudományi Társaság korábbi alelnökének a regionális tudomány területén vég- 
zett kiemelkedő kutatói, oktatói és iskolaépítő tevékenysége elismeréseként ítélték oda. Első alkalommal került sor Díszoklevél adományozására, amelyet a társaság alapszabálya szerint azon tag kaphat meg, aki kimagasló tudományos eredménnyel, példaadó szakmai, közösségi aktivitással erre rászolgált. Az elismerést Baranyi Béla, a Debreceni Egyetem professor emeritusa, az MRTT Északalföldi tagozatának leköszönő vezetője, valamint Korompai Attila, a Budapesti Corvinus Egyetem nyugalmazott egyetemi docense, az MRTT Számvizsgáló Bizottságának korábbi elnöke vehette át. A társaság nyolcadik alkalommal hirdette meg a Kiváló Ifjú Regionalista Díj felhívását, amelyet az MRTT tagozatvezetőkkel kibővített elnöksége Tóth Balázs Istvánnak, a Nyugat-magyarországi Egyetem Közgazdaságtudományi Kar egyetemi adjunktusának ítélt oda, elismerve a regionális tudomány művelésében elért értékes eredményeit.

A vándorgyülés második napján tizenkét tematikus - köztük egy angol nyelvű - szekcióban folytatódott a tudományos diskurzus. A város mint kutatási fókusz multidiszciplinaritását jelzik a szekciótematikák is, amelyek a városökológiától a városszociológián és a városmarketingen át a város-vidék, valamint a határ menti kapcsolatokig terjedtek, 90 előadás keretében, melyek elérhetők a társaság honlapján: http://www.mrtt.hu/. 